\title{
Notulae to the Italian flora of algae, bryophytes, fungi and lichens: 3
}

Sonia Ravera', Annalena Cogoni' ${ }^{2}$ Alfredo Vizzini ${ }^{3}$, Michele Aleffi ${ }^{4}$, Silvia Assini ${ }^{5}$, Matteo Barcella ${ }^{5}$, Wolfgang von Brackel ${ }^{6}$, Stefania Caporale 7 , Zuzana Fačkovcová ${ }^{8}$, Giorgia Filippino $^{2}$, Gabriele Gheza ${ }^{5}$, Daniela Gigante', Luca Paoli $^{10}$, Giovanna Potenza" ${ }^{11}$, Silvia Poponessi ${ }^{9}$, Filippo Prosser ${ }^{12}$, Domenico Puntillo ${ }^{13}$, Michele Puntillo ${ }^{13}$, Roberto Venanzoni ${ }^{9}$

I via del Labaro 54, 00188 Roma, Italy 2 Dipartimento di Scienze della Vita e dell'Ambiente, Università degli Studi di Cagliari, viale Sant'Ignazio da Laconi 13, 09123 Cagliari, Italy 3 Dipartimento di Scienze della Vita e Biologia dei Sistemi, Viale P.A. Mattioli 25, 10125 Torino, Italy 4 Scuola di Bioscienze e Medicina Veterinaria, Università degli Studi di Camerino, via Pontoni 5, 62032 Camerino (Macerata), Italy 5 Dipartimento di Scienze della Terra e dell'Ambiente, Università di Pavia, Via S. Epifanio 14, 27100 Pavia, Italy 6 Institut für Vegetationskunde und Landschaftsökologie, Georg-Eger-Str. 1b, DE-91334 Hemhofen, Germany 7 Dipartimento di Bioscienze e Territorio, Università degli Studi del Molise, C.da Fonte Lappone, 86090 Pesche (Isernia), Italy 8 Institute of Botany, Slovak Academy of Sciences, Dúbravská cesta 9, SK-84523 Bratislava, Slovakia 9 Dipartimento di Chimica, Biologia e Biotecnologia, Università degli Studi di Perugia, Borgo XX giugno 74, 06121 Perugia, Italy 10 Dipartimento di Scienze della Vita, Università degli Studi di Siena, Via P.A. Mattioli 4, 53100 Siena, Italy II Scuola di scienze Agrarie, Forestali, Alimentari ed Ambientali, Dipartimento di Biologia, Difesa e Biotecnologie Agro-Forestali, Università della Basilicata, Viale dell'Ateneo Lucano 10, 85100 Potenza, Italy 12 Fondazione Museo Civico di Rovereto, Largo S. Caterina 41, 38068 Rovereto (Trento) 13 Museo di Storia Naturale della Calabria ed Orto Botanico, Università della Calabria, 87036 Arcavacata di Rende (Cosenza), Italy

Corresponding author: Sonia Ravera (sonia.ravera@unimol.it)

Academic editor: L. Peruzzi | Received 26 February 2017 | Accepted 13 March 2017 | Published 23 March 2017

Citation: Ravera S, Cogoni A, Vizzini A, Aleffi M, Assini S, Barcella M, von Brackel W, Caporale S, Fačkovcová Z, Filippino G, Gheza G, Gigante D, Paoli L, Potenza G, Poponessi S, Prosser F, Puntillo D, Puntillo M, Venanzoni R (2017) Notulae to the Italian flora of algae, bryophytes, fungi and lichens: 3. Italian Botanist 3: 17-27. doi: 10.3897/ italianbotanist. 3.12432

\begin{abstract}
In this contribution, new data concerning bryophytes, fungi and lichens and of the Italian flora are presented. It includes new records and confirmations for the bryophyte genera Dicranodontium, Fontinalis, Lophocolea and Riccia, the fungal genus Diplolaeviopsis, the lichen genera Agonimia, Cladonia, Protoparmelia, Rhizocarpon, and Scytinium.
\end{abstract}

Copyright Sonia Ravera et al. This is an open access article distributed under the terms of the Creative Commons Attribution License (CC BY 4.0), which permits unrestricted use, distribution, and reproduction in any medium, provided the original author and source are credited. 


\section{Keywords}

Ascomycota, Bryidae, Marchantiidae, Jungermanniidae, floristic data

\section{How to contribute}

The text of the records should be submitted electronically to: Cecilia Totti (c.totti@univpm.it) for algae, Annalena Cogoni (cogoni@unica.it) for bryophytes, Alfredo Vizzini (alfredo.vizzini@unito.it) for fungi, Sonia Ravera (sonia.ravera@unimol.it) for lichens.

\section{Floristic records}

\section{BRYOPHYTES}

Dicranodontium denudatum (Brid.) E.Britton (Leucobryaceae)

+ UMB: Monte Serano (Perugia), in the Special Areas of Conservation (SAC) IT5210047 Monti Serano - Brunette (sommità) on humicolous slope in woodland (UTM WGS84: 33T 320531.47483336), 1340 m, 14 October 2013, S. Poponessi, M. Aleffi (BPERU). - Species new for the flora of Central Italy.

According to Aleffi et al. (2008), the presence in Italy of Dicranodontium denudatum is restricted to a number of northern localities. However, its occurrence in Veneto, Liguria, Emilia-Romagna, Toscana, Campania and Sardegna has not been confirmed over the last 50 years. The site in Umbria is characterized by the presence of Holm oak (Quercus ilex L.) woods. This record is also interesting because the reported altitudinal range of the species is generally lower in Europe, up to about $1000 \mathrm{~m}$ (Smith 2004, Poponessi et al. 2014). Dicranodontium denudatum does not seem to be widespread in the Mediterranean basin, but it is widely distributed in Europe, assigned to the European Boreal-montane floristic element. It usually grows on damp shaded rocks, decaying wood and peaty soil in woods and occasionally in open habitats (Smith 2004). Dicranodontium denudatum is a species threatened with extinction in several European countries: it is considered as Critically Endangered (CR) in Ireland, Vulnerable (VU) in Bulgaria and Endangered (EN) in Hungary. In Italy, the data are not usfficient for an assessment (Hodgetts 2015).

S. Poponessi, M. Aleffi, D. Gigante, R. Venanzoni

Fontinalis hypnoides C.Hartm. var. duriaei (Schimp.) Kindb. (Fontinalaceae)

+ VEN: 400 m NW of Roversola, Oppeano, (Verona), in Fosso Ladretto, with Potamogeton nodosus Poir. (UTM WGS84: 32T 663016.5023250), 30 m, 23 October 2015, F. Prosser (Herb. Prosser No. 00084). - Species new for the flora of Veneto. 
The only Fontinalis reported for Veneto is F. antipyretica Hedw. (Aleffi et al. 2008), from which Fontinalis hypnoides var. duriaei can be easily distinguished for the not keeled stem leaves. Fontinalis hypnoides var. duriaei differs from other Italian species for plane (not concave) stem leaves and for leaf margin without 1-4 rows of elongate cells. Fontinalis hypnoides var. duriaei is reported in northern Italy only for Lombardia, but not confirmed after 1950, and for Emilia-Romagna; it occurs also in Toscana, Lazio before 1950, Sardegna and Sicilia (Aleffi et al. 2008). The similar F. hypnoides var. hypnoides is reported in northern Italy only for Lombardia, but without confirmation after 1950. Unfortunately, we have no information about the population size of $F$. hypnoides var. duriaei and its diffusion near Roversola.

F. Prosser

\section{Lophocolea bidentata (L.) Dumort. (Geocalycaceae)}

+ VEN: Sass Negher (Belluno), near Serrai di Sottoguda Natural Reserve and Marmolada Glacier, groove in the rock (UTM WGS84: 32T 726144.5145940), $1403 \mathrm{~m}$, 8 December 2016, S. Poponessi (PERU). - Species confirmed for the flora of Veneto.

Lophocolea bidentata is an austral-tropical montane liverwort species (Dierßen 2001). It has been widely recorded in central and northern Italy (Aleffi et al. 2008), but the last record in Veneto dates back to the early 1900s (Massalongo 1903). The area of occurrence is characterized by a moist gorge in a rocky dolomitic wall, along the border between beech and coniferous trees. Associate species include Plagiopus oederianus (Sw.) H.A.Crum. \& L.E.Anderson var. oederianus, Fissidens adianthoides Hedw., Nekera crispa Hedw., Jungermannia gracillima Sm., Cephalozia bicuspidata (L.) Dumort., Lejeunea cavifolia (Ehrh.) Lindb. and Ptychostomum pseudotriquetrum (Hedw.) J.R.Spence \& H.P.Ramsay var. bimum (taxon to be confirmed, according to Hodgetts 2015). Two ferns are also associate: Asplenium ruta-muraria L. subsp. dolomiticum Lovis \& Reichst., and Asplenium trichomanes L. Lophocolea bidentata is widely distributed in Europe and is considered Vulnerable (VU) in Finland and Near Threatened (NT) in Italy (Hodgetts 2015).

S. Poponessi, M. Aleffi, D. Gigante, R. Venanzoni

\section{Riccia cavernosa Hoffm. (Ricciaceae)}

+ CAL: Lago Cecita (Cosenza), in the Sila National Park on muddy soil along the lakeshore (UTM WGS84 33S 630173.4358704), 1137 m, 13 September 2014, D. Puntillo (CLU No. 4090). - Species new for the flora of Calabria.

The species is recognizable for the perforations to the branch tips of the thallus and for their triangular-globular, polar spores incompletely reticulate. Distal face with 
smooth, irregular low ridges, proximal face often granulate; covered with simple or branching ridges (Dierßen 2001). Riccia cavernosa normally lives on seasonally wet or flooded habitats. It is a cosmopolitan species widespread known in Europe and in the Mediterranean Basin (Ros et al. 2007, Hodgetts 2015). This species is known in Italy for Lombardia, Trentino-Alto Adige, Emilia Romagna, Abruzzo, Puglia and Sicilia (Aleffi et al. 2008). In Europe, it is assessed as Endangered (EN) in Norwey and Austria, Vulnerable (VU) in Germany and Critically Endangered (CR) in Portugal and Switzerland (Hodgetts 2015).

D. Puntillo

\section{FUNGI}

\section{Diplolaeviopsis ranula Giralt \& D.Hawksw. (encoelioid-clade)}

+ CAM: Gole del Bussento, Morigerati (Salerno), on Lecanora strobilina (Spreng.) Kieff. (UTM WGS84 33T 547000.4443740), 220 m, 28 July 1997, D. Puntillo (CLU No. 13436; dupl. Hb Diederich, Luxembourg). - Species new for the flora of Italy (Campania).

This species is a lichenicolous pycnidial coelomycete, commensal to pathogens on the apothecia and thalli of the Lecanora strobilina (Spreng.) Kieff. complex, and recognized by the characteristic 1(-2)-septate, often asymmetric, tadpole-shaped conidia (Giralt and Hawksworth 1991). This lichenicolous fungus is not included in the Italian preliminary check-list (Brackel 2016). It has been reported so far from France, Great Britain, Luxembourg, Portugal, Spain, Brazil and the USA, as associated with Lecanora strobilina and Lecanora strobilinoides Giralt \& Gómez-Bolea (Giralt and Hawksworth 1991, Bricaud et al. 1992, Diederich et al. 1992, van den Boom and Giralt 1999, Earland-Bennett 1999, Diederich 2003, Hodkinson 2010). Its sexual morph has been recently described by Suija et al. (2015) and molecularly confirmed by Etayo et al. (2015). Phylogenetically it clusters in the encoelioid-clade (Helotiales) where it is sister to the genus Macroskyttea Etayo, Flakus, Suija \& Kukwa (Etayo et al. 2015).

D. Puntillo, M. Puntillo, A. Vizzini

\section{LICHENS}

\section{Agonimia octospora Coppins \& P.james (Verrucariaceae)}

+ CAM: Pisciotta (Salerno), on Olea europaea L. (UTM WGS84:33T 519127.4440793), 230 m, 22 February 2011, leg. S. Ravera, G. Brunialti, det. S. Ravera (Herb. Ravera); Ottati (Salerno), on Quercus ilex L. (UTM WGS84: 33T 526762.4479360), 630 m, 
12 April 2011, leg. S. Ravera, G. Brunialti, det. S. Ravera (Herb. Ravera). - Species new for the flora of Southern Italy (Campania).

Agonimia octospora is an epiphytic microlichen with squamulose thallus and more or less scattered perithecia, often sterile. Growing on basal parts of old trees, usually on bark among mosses, it is overlooked in the field not only for the small squamules of the thallus $(0.05-0.25 \times 0.05-0.12 \mathrm{~mm})$. These two records confirm the scarce poleotolerance (Nimis 2016) of the species: both of the sites include undisturbed centenary trees in an olive orchard (Pisciotta) and in an old-growth wood (Ottati). Agonimia octospora is included in the national red list of epiphytic lichens as "Data Deficient" (Nascimbene et al. 2013).

S. Ravera

\section{Agonimia opuntiella (Buschardt \& Poelt) Vězda (Verrucariaceae)}

+ TOS: Collina di Vinacciano, "via di Piastreta e Collina", Serravalle Pistoiese (Pistoia), on Quercus pubescens Willd. (UTM WGS84: 32T 650152.4861724), $225 \mathrm{~m}$, 22 August 2016, Z. Fačkovcová, L. Paoli (SIENA); Collina di Vinacciano, in the proximity of the cemetery of Vinacciano, Serravalle Pistoiese (Pistoia), on Q. pubescens (UTM WGS84: 32T 650153.4861118), 160 m, 22 August 2016, Z. Fačkovcová, L. Paoli (SIENA); "via Forniccione", Serravalle Pistoiese (Pistoia), on Q. pubescens (UTM WGS84: 32T 652397.4861553), 65 m, 26 August 2016, Z. Fačkovcová, L. Paoli (SIENA). - Species confirmed for the flora of Toscana.

The species has a squamulose thallus, with minutely papillate and hairy surface. Due to the small dimensions, in the field it could be confused with young specimens of Physconia servitii (Nádv.) Poelt or Phaeophyscia hirsuta (Mereschk.) Essl. Agonimia opuntiella is rare and likely underestimated in Italy. A previous record in Toscana has been reported for the province of Grosseto, on Olea europaea L. (Brackel 2015).

L. Paoli, Z. Fačkovcová

\section{Chaenotheca hispidula (Ach.) Zahlbr. (Coniocybaceae)}

+ ABR: Vallevò, Rocca San Giovanni (Chieti), on bark of Quercus pubescens Mill. in Fosso della Farfalla (UTM WGS84: 33T 2476175.4681392), 69 m, 6 November 2010, S. Caporale, T. Pagliani, F. Piccoli, R. Veri (Herb. S. Caporale). - Species new for the flora of Abruzzo.

It is a cosmopolitan species, widely distributed in Europe from the Boreal to the Mediterranean-Mountain belt. In Italy it is found rarely and its presence was probably overestimated in the past (Zedda 2002). It colonizes preferentially cavities in the bark and at the base of old trees, especially oaks, in damp and non-eutrophic woods 
(Nimis 2016). The presence of lichens belonging to the 'Caliciales' group is considered indicative of environmental quality and ecological continuity (Ravera and Puntillo 2014). It is included in the national red list of epiphytic lichens as "Near Threatened" (Nascimbene et al. 2013).

S. Caporale

\section{Cladonia polycarpoides Nyl. (Cladoniaceae)}

+ PIE: Cascina Casone, Pombia (Novara), within the Natural Park Valle del Ticino, on sandy-pebbly soil in a dry grassland (UTM WGS84: 32T 475582.5054277), 172 m, 10 June 2016, G. Gheza (Herb. Gheza); Barbelera, Oleggio (Novara), within the Natural Park Valle del Ticino, on sandy-pebbly soil in a dry grassland (UTM WGS84: 32T 474874.5051835), 161 m, 21 April 2016, G. Gheza (Herb. Gheza); Marcetto, Oleggio (Novara), within the Natural Park Valle del Ticino, on sandy-pebbly soil in a dry grassland (UTM WGS84: 32T 475072.5051295), 158 m, 21 April 2016, G. Gheza (Herb. Gheza); Tenuta Bornago, Cameri (Novara), within the Natural Park Valle del Ticino, on sandy-pebbly soil in a dry grassland (UTM WGS84: 32T 476694.5044401), 141 m, 17 June 2016, G. Gheza (Herb. Gheza); Villa Giulia, Cerano (Novara), within the Natural Park Valle del Ticino, on sandy-pebbly soil in a dry grassland (UTM WGS84: 32T 487030.5027303), 99 m, 25 March 2016, G. Gheza (Herb. Gheza); surroundings of Canale Cavour, Greggio (Vercelli), near the boundary of the Natural Park Lame del Sesia, on soil in a pioneer dry grassland (UTM WGS84: 32T 452897.5034279), 167 m, 3 May 2016, G. Gheza (Herb. Gheza); Gerbido di Greggio (Vercelli), within the Natural Park Lame del Sesia, on soil in an evolved dry grassland (UTM WGS84: 32T 452849.5032860), 160 m, 4 March 2016, G. Gheza (Herb. Gheza); Gerbido di Villata (Vercelli), within the Natural Park Lame del Sesia, on sandy-pebbly soil in a dry grassland (UTM WGS84: 32T 453022.5026746), 138 m, 4 March 2016, G. Gheza (Herb. Gheza); Torrette di Frassineto, Frassineto Po (Alessandria), surroundings of the confluence between the rivers Sesia and Po, within the River Park "Parco fluviale del Po tratto vercellese/alessandrino e Riserva Naturale del Torrente Orba", on sandy-silty soil in a dry grassland (UTM WGS84: 32T 467121.4998255), 99 m, 17 February 2016, G. Gheza (Herb. Gheza). - Species new for the flora of Piemonte.

+ LOM: Ansa di Castelnovate, Vizzola Ticino (Varese), within the Natural Park Valle del Ticino, on sandy soil in a dry grassland (UTM WGS84:32T 473961.5052563), $164 \mathrm{~m}, 16$ June 2016, G. Gheza (Herb. Gheza); surroundings of the Ticino river near Bernate Ticino (Milano), within the Natural Park Valle del Ticino, on sandy soil in a dry grassland (UTM WGS84: 32T 484052.5035066), 117 m, 25 March 2016, G. Gheza (Herb. Gheza); Tenuta La Fagiana, Pontevecchio di Magenta (Milano), within the Natural Park Valle del Ticino, on sandy soil in a dry grassland (UTM WGS84: 32T 486481.5030650), 109 m, 26 April 2016, G. Gheza (Herb. Gheza); Bosco Ron- 
chi, Vigevano (Pavia), within the Natural Park Valle del Ticino, on sandy soil in a dry grassland (UTM WGS84: 32T 495866.5013406), 78 m, 30 May 2016, G. Gheza (Herb. Gheza). - Species confirmed for the flora of Lombardia.

Cladonia polycarpoides is known from only few administrative regions in Italy (Nimis 2016). The only literature record in Lombardia, from the lower Valtellina (Rossi 1991), refers to a single site, while the species is new for Piemonte. On the basis of the new records reported here, which extend the Italian range of the species to the Po Plain, C. polycarpoides seems to be well distributed in dry grasslands of the Thero-Airion Tüxen ex Oberdorfer 1957 located on acidic substrates along the course of two main rivers (Sesia and Ticino). It was always found in the Cladonietum foliaceae Klement 1953 emend. Drehwald 1993.

G. Gheza

Cladonia furcata (Huds.) Schrad. subsp. subrangiformis (L. Scriba ex Sandst.) Pišút (Cladoniaceae)

+ PIE: Portanuova, Casal Cermelli (Alessandria), surroundings of Cascina Merlana, on basic sandy-pebbly soil in a dry grassland (UTM WGS84: 32T 471806.4962778), 109 m, 10 May 2016, G. Gheza, S. Assini (Herb. Gheza); between Villalvernia and Cassano Spinola (Alessandria), bird ringing station near the Scrivia river, on calcareous sandy-pebbly soil (UTM WGS84: 32T 488531.4959878), 162 m, 14 April 2016, G. Gheza, S. Assini (Herb. Gheza); Gremiasco (Alessandria), surroundings of the Osservatorio Astronomico di Guardamonte, on sandstone outcrops (UTM WGS84: 32T 506270.4962306), 682-687 m, 9 December 2016, G. Gheza (Herb. Gheza). - Subspecies confirmed for the flora of Piemonte.

+ LOM: Cecima (Pavia), surroundings of the Osservatorio Astronomico di Guardamonte, on soil in a dry grassland (UTM WGS84: 32T 506264.4962342), 690 m, 9 December 2016, G. Gheza (Herb. Gheza); Fontana di Nivione, Varzi (Pavia), on clay soil on badlands (UTM WGS84: 32T 514388.4962082), 490-501 m, 10 November 2016, G. Gheza, M. Barcella (Herb. Gheza, Herb. Barcella); San Michele di Nivione, Varzi (Pavia), on calcareous soil (UTM WGS84: 32T 514671.4960675), 503-508 m, 10 November 2016, G. Gheza, M. Barcella (Herb. Gheza, Herb. Barcella); Cella di Varzi (Pavia) surroundings of Castello Malaspina, on arenaceous soil (UTM WGS84: 32T 514394.4958621), 705-710 m, 10 November 2016, G. Gheza, M. Barcella (Herb. Gheza, Herb. Barcella). - Subspecies new for the flora of Lombardia.

+ EMI: Bobbio (Piacenza), ophiolite outcrop east of the mount Pan Perduto, on soil (UTM WGS84: 32T 528845.4963028), 995-997 m, 25 June 2013, G. Gheza (Herb. Gheza). - Subspecies confirmed for the flora of Emilia Romagna.

Cladonia furcata subsp. subrangiformis is a terricolous species found typically on basic-calcareous soil, with a rather continental distribution (Nimis 1993). It was previously known in two localities in Piemonte and three in Emilia Romagna (see literature cited 
by Nimis 1993, 2016); moreover, all the records from Piemonte are very old. The new records reported here extend the range of the species to planitial calcareous dry grasslands located south of the Po river in Piemonte and to the Appennino Pavese in the southernmost part of Lombardia. The species seems rather common in terricolous cryptogam communities on pioneer calcareous, arenaceous and clayey substrates and, therefore, it is probably more widespread than believed until now in the northern Apennines, especially in lichen communities of the Toninion sedifoliae Hadač 1948 emend. Wirth 1995 on badlands, calcareous rock outcrops and similar substrates.

G. Gheza, M. Barcella, S. Assini

\section{Protoparmelia badia (Hoffm.) Hafellner (Parmeliaceae)}

+ BAS: Cerro Falcone, Calvello (Potenza), on acid rock (UTM WGS84 33T 567960.4478689, 963 m. 7 August 2012, G. Potenza, D. Puntillo (CLU No. 16685). - Species new for the flora of Basilicata.

Described by Hoffmann (1795) as Verrucaria badia and transferred to the genus Lecanora by Acharius (1810). Due to the placodioid thallus, the species was transferred to the genus Protoparmelia by Hafellner (1984). Bipolar species in alpine and mountainous areas of Europe, North America, Asia, South America, New Zealand and Antarctica. It grows on well-lit, hard, siliceous rocks. In Italy, it was recorded from Friuli to Sicily (Nimis 2016).

G. Potenza, D. Puntillo

\section{Rhizocarpon dinothetes Hertel \& Leuckert (Rhizocarpaceae)}

+ SAR: Monte Limbara (Olbia-Tempio), Multa Ragna, on siliceous rock, parasitic on Protoparmelia montagnei (Fr.) Poelt \& Nimis (UTM WGS84: 32T 511531.4522312), 975 m, 3 September 2014, W. v. Brackel, G. v. Brackel (Herb. Brackel 7858). - Species confirmed for the flora of Sardegna.

This is the second report for Italy after that of R. Türk in 1986 at the Passo La Variante some kilometers away from the location of the recent find (Nimis and Poelt 1987). Rhizocarpon dinothetes lives parasitically on Protoparmelia badia (Hoffm.) Hafellner and $P$. montagnei on well-lit siliceous rocks. It is easily recognized by its allegiance to the host lichen, the bright greenish-yellow thallus, roundish, black, marginate apothecia and small (sub-)muriform ascospores of c. 13.5-24.5 × 8.5-11.5 $\mu \mathrm{m}$. Except for Sardegna, it was known until now only from Austria and Spain. 


\section{Scytinium schraderi (Ach.) Otálora, P.M.Jørg. \& Wedin (Collemataceae)}

+ PIE: between Villalvernia and Cassano Spinola (Alessandria), bird ringing station near the Scrivia river, on calcareous sandy-pebbly soil (UTM WGS84: 32T 488531.4959878), 162 m, 5 May 2016, G. Gheza (Herb. Gheza). - Species confirmed for the flora of Piemonte.

+ LOM: Basella (Bergamo), in the Nature Reserve Basella-Malpaga, near the Serio river, on calcareous soil (UTM WGS84: 32T 557658.5051025), $182 \mathrm{~m}, 31 \mathrm{March}$ 2016, G. Gheza (Herb. Gheza). - Species new for the flora of Lombardia.

Scytinium schraderi is a cyanolichen found on calcareous soil and rock. It was previously known for Piemonte and only from one locality (Nimis 2016), while it is new for Lombardia. The two sites described here are rather similar, being located in dry grasslands on calcareous substrates along the planitial course of two main rivers. Scytinium schraderi was sampled within rather pioneer stands of a lichen-moss community referable to the Toninio-Psoretum decipientis Stodieck, 1973.

G. Gheza

\section{Acknowledgements}

Gabriele Gheza thanks Paola Palazzolo (Parco Fluviale del Po e dell'Orba), Agostino Pela (Parco Naturale delle Lame del Sesia) and Valentina Parco (Parco Naturale della Valle del Ticino Lombardo) for having revealed some of the sites in which Cladonia polycarpoides was found.

\section{References}

Acharius E (1810) Lichenographia universalis. Gottingae, apud Iust. Frid. Danckwerts, 407 pp. Aleffi M, Tacchi R, Cortini Pedrotti C (2008) Check-list of the Hornworts, liverworts and Mosses of Italy. Bocconea 22: 5-254.

Boom PPG van den, Giralt M (1999) Contribution to the flora of Portugal, lichens and lichenicolous fungi II. Nova Hedwigia 68: 183-196.

Brackel von W (2015) Lichenicolous fungi from Central Italy with notes on some remarkable hepaticolous, algicolous and lichenized fungi. Herzogia 28: 212-218. https://doi. org/10.13158/heia.28.1.2015.212

Brackel von W (2016) Preliminary checklist of the lichenicolous fungi of Italy. Notiziario della Società Lichenologica Italiana 29: 95-145.

Bricaud O, Coste C, Le Cœur D, Glenn M, Ménard T, Roux C (1992) Champignons lichénisés et lichénicoles de la France méridionale: espèces nouvelles et intéressantes (VI). Bulletin de la Société Linnéenne de Provence 43: 81-96. 
Diederich P (2003) New species and new records of American lichenicolous fungi. Herzogia 16: 41-90.

Diederich P, Lambinon J, Sérusiaux E, van den Boom P (1992) Lichens et champignons lichénicoles nouveaux ou intéressants pour la flore de la Belgique et des régions voisines. VI. Belgian Journal of Botany 125: 137-150.

Dierßen K (2001) Distribution, ecological amplitude and phytosociological characterization of European bryophytes. Bryophytorum Biblioteca 56, 289 pp.

Earland-Bennett PM (1999) Diplolaeviopsis ranula. New, rare and interesting British lichen and lichenicolous fungus records. British Lichen Society Bulletin 84: 48.

Etayo J, Flakus A, Suija A, Kukwa M (2015) Macroskyttea parmotrematis gen. et sp. nov. (Helotiales, Leotiomycetes, Ascomycota), a new lichenicolous fungus from Bolivia. Phytotaxa 224: 247-257. https://doi.org/10.11646/phytotaxa.224.3.3

Giralt M, Hawksworth DL (1991) Diplolaeviopsis ranula, a new genus and species of lichenicolous coelomycetes growing on the Lecanora strobilina group in Spain. Mycological Research 95: 759-761. https://doi.org/10.1016/S0953-7562(09)80828-9

Hafellner RJ (1984) Studien in Richtung einer natürlicheren Gliederung der Sammelfamilien Lecanoraceae und Lecideaceae. In: Hertel H, Oberwinkler F (Eds) Beiträge zur Lichenologie. Festscrift J. Poelt, vol 79, Beiheft zur Nova Hedwig, 241-371.

Hodgetts NG (2015) Checklist and country status of European bryophytes - towards a new Red List for Europe. Irish Wildlife Manuals, No. 84. National Parks and Wildlife Service, Department of Arts, Heritage and the Gaeltacht. Ireland, 125 pp.

Hodkinson BP (2010) A first assessment of lichen diversity for one of North America's 'Biodiversity Hotspots' in the Southern Appalachians of Virginia. Castanea 75: 126-133. https:// doi.org/10.2179/09-033.1

Hoffmann GF (1796) Deutschlands Flora oder botanisches Taschenbuch. Zweyter Theil für das Jahr 1795. Cryptogamie. B.I.I. PalmlErlangen: 182. https://doi.org/10.5962/bhl.title.126793

Massalongo C (1903) Le epatiche dell'Erbario Crittogamico Italiano. Comunicazione all' Accademia di Scienze Mediche e Naturali di Ferrara, 1-20.

Nascimbene J, Nimis PL, Ravera S (2013) Evaluating the conservation status of epiphytic lichens of Italy: a red list. Plant Biosystems 147: 898-904. https://doi.org/10.1080/1126 3504.2012.748101

Nimis PL (1993) The lichens of Italy: an annotated catalogue. Monografie XII. Museo Regionale di Scienze Naturali di Torino, 897 pp.

Nimis PL (2016) The Lichens of Italy. A second annotated catalogue. EUT. Trieste. 740 pp.

Nimis PL, Poelt J (1987) The lichens and lichenicolous fungi of Sardinia (Italy). An annotated list. Studia Geobotanica 7 (suppl. 1), 269 pp.

Poponessi S, Mariotti MG, Aleffi M, Venanzoni R (2014) Bryophytic similarity of the Italian regions with a focus on the Ligurian region. Plant Biosystems 148: 851-856. https://doi. org/10.1080/11263504.2014.949330

Ravera S, Puntillo D (2014) Licheni a spillo. Piccola guida alle Caliciales d'Italia. Ministero dell'Ambiente e della Tutela del Territorio e del Mare e Università degli Studi del Molise, 154 pp. 
Ros RM, Mazimpaka V, Abou-Salama U, Aleffi M, Blockeel TL, Brugués M, Cano MJ, Cros RM, Dia MG, Dirkse GM, El-Saadawi W, Erdağ A, Ganeva A, González-Mancebo JM, Herrnstadt I, Khalil K, Kürschner H, Lanfranco E, Losada-Lima A, Refai MS, RodríguezNuñez S, Sabovljević M, Sérgio C, Shabbara H, Simsim M, Södertröm L (2007) Hepatics and Anthocerotes of the Mediterranean, an annotated checklist. Cryptogamie, Bryologie 28: 351-437.

Ravera S, Puntillo D (2014) Licheni a spillo. Piccola guida alle Caliciales d'Italia. Ministero dell'Ambiente e della Tutela del Territorio e del Mare e Università degli Studi del Molise, $154 \mathrm{pp}$.

Rossi G (1991) Sulla presenza di Cytinus hypocistis (L.) L. in Lombardia e nelle Alpi italiane. Atti dell'Istituto di Botanica e del Laboratorio Crittogamico dell'Università di Pavia, ser. 7, 10: 105-111.

Smith AJE (2004) The moss flora of Britain and Ireland ( $2^{\text {nd }}$ edn). Cambridge University Press, 1012 pp. https://doi.org/10.1017/CBO9780511541858

Suija A, Ertz D, Lawrey JD, Diederich P (2015) Multiple origin of the lichenicolous life habit in Helotiales, based on nuclear ribosomal sequences. Fungal Diversity 70: 55-72. https:// doi.org/10.1007/s13225-014-0287-4

Zedda L (2002) The epiphytic lichens on Quercus in Sardinia (Italy) and their value as ecological indicators. Englera 24: 1-457. 